\title{
Are the Ukwuanis Benin or Igbo? A Study of Origin and Migration
}

\author{
Paul O. Opone \\ http://dx.doi./org/10.4314/ujah.v18i3.7
}

\begin{abstract}
The identity of Ukwuani people has for some time now generated debate among their leaders, ethnic historians, and other scholars of Ukwuani extraction. Such debates have produced a dominant perspective that the Ukwuanis are Benin people in diaspora without going to the field to confirm such a claim. This paper, therefore, participated in the on-going debate. The historical method of descriptive analysis was deployed. This method is most appropriate for this work because it offered the opportunity to interrogate the traditions of origins of the different Ukwuani clans. The findings indicate that Ukwuani people are Igbo in origin, and the claim of origin from Benin which textbook generalizations tended to portray is a recent contraption made possible by feedback in oral tradition.
\end{abstract}

\section{Introduction}

A common problem among many African societies is the issue of origin, and it touches the very foundation of the identity of a people. Yet, the traditions of origins of many societies pose problems to the historian because, as Atanda has noted, questions about origin form parts, indeed constitute the first of the natural series and sequence of questions which homo-sapiens must ask. Such questions constitute an index of man's historical consciousness. If they are lacking, then, man ceases to be a rational 
being (63). This is why man has insistently demanded to know himself and where he came from to his present location. It is because of the need to meet this insistent demand as Afigbo observes, "that scholars have continued, and will continue, to blunt the cutting edge of their intellectual weapon by striking at this interactive problem" (64)). The Ukwuani is no exception in this regard. They want to know who they are and where they came from.

The Ukwuani is one of the three sub groups that make up the Igbo west of the River Niger; the others are Enuani and Ika. These three sub groups are now collectively regarded as Anioma (Good Land), geo-politically located in Nigeria's Delta State. Within the Western Igbo area, the Ukwuani inhabit the low-lying and swampy area within latitude North 5, $50-70$ and Longitude East 6' - 6'- 50 according to Mallison. In Forde and Jones' classifications, the Ukwuani people are regarded as Southern Ika Ibo (48). It comprises fifteen clans, namely Abbi, Akoku, Amai, Ebedei, Emu, Eziokpor, Ezionum, Obiaruku, Ogume, OnichaUkwuani, Umuebu, Umukwuata, Umutu, Utagba-Ogbe and Utagba-Uno. The name Ukwuani is a topographical construct deriving from their environment. It means low- land dwellers which conform to the Igbo way of naming their settlement according to the geographical features.

The origin of Ukwuani people has received attention from scholars. For instance, Okolugbo believes that three migration waves led to the peopling of Ukwuani country. He claims that the first and second waves during the $15^{\text {th }}$ and $17^{\text {th }}$ centuries respectively came from Benin kingdom. He attributes the third wave which he claims was a mixture of Benin and Igbo migrants to the founding of Aboh and UmuNze clans of Umukwata, Amai, Orogun, Abbi, Amai, and the Akashiada group of communities (6). 
He further describes the founders as Edo conquerors who carried expedition to Aboh, where they sojourned before moving down to the present site of Umukwata, from where the rest communities or clans were founded. In the same vein, Ozah traces the origin of the Ukwuani people to Benin, claiming that their forebears were Benin people who came to settle in what is now Ukwuani land. Okolugbo and Ozah clearly make sweeping generalizations that Ukwuani people are Benin in origin without investigating the history of different Ukwuani clans and communities.

Recent study by Ojieh attributes the peopling of the Ukwuani area to two main migration waves, the first from Benin towards the end of the $15^{\text {th }}$ century and the second being those of Eastern Igbo in the early part of the $16^{\text {th }}$ century. He though talks about the third group who claims autochthonous origin dating into antiquity. However, Ojieh does not focus on Ukwuani origin which is why details of the early history of the people are not provided. In general, the dominant narrative is that Ukwuani people are Binis in diaspora. This branch of historiography is now held by some who make references to "Ethnologue" that classifies Ukwuani as an ethnic group outside the larger Igbo ethnic group.

Often, what comes from their claims do not reflect the historical reality. As a result, the people's past is distorted and they now found themselves contending with identity crisis. This is why many of them now say they are not Igbo but Ukwuani, implying that they sprouted from the ground where they are found today. But with exception to Biblical creation in the Garden of Eden, no human group sprouted from the ground or descended from heaven, which is why the historian must focus on finding the place of ancestral origins. Of course, the process of defining who is Igbo and who is not has had important social and political 
consequences, and therefore, warrants our attention here with the case of Ukwuani.

\section{Traditions of Origins and Migrations}

As Isichei says, the history of many people begins with a migration and a founding father (19), and these histories are contained in the peoples' traditions which are either in recorded form or orally transmitted to the researcher historian. Thus, this section interrogates the traditions of origins of Ukwuani clans.

\section{Abbi Clan}

According to tradition, Abbi clan was founded by one Amacha from Echalla-Ukwu in Igbo country east of the Niger. Amacha and his brother (Ukwata) are said to have gotten to Aboh in one of their hunting expeditions, and sojourned there, where they met Effi and Amai, with whom they migrated to Ukwuani hinterland as a result of a quarrel with the Aboh people, in the course of which they founded the Elovie quarters of Abbi which were jointly called Kanyibilinebeni (let us settle here) later shortened to Abbi Echalla (Ezulu). This was after Amacha had established his presence and authority in the new domain by staking a neubouldialaevis plant locally called "Egbo Ogillisi”'(Enuenwosu).

They were later joined by two other migrant groups led by Ewolokpo and OkpalaOgwezi. The latter groups were said to have settled at Abbi at different times. The three families lived at what came to be known as Elovie quarter of Abbi. After some time, Owolukpo, Udu and OkpalaOgwezi (who was of Ubulu origin) and his followers moved further to form the second quarter of Abbi known as Umia. Ukwata (Amacha's brother) and his children left to found what is today Umukwata (children of Ukwata) clan. The 
first village they founded is called Owa. The village still returns to Abbi for religious purposes (Ezulu).

\section{Akashiada Group}

This consists of Eziokpor, Ezionum, Obiaruku and Umuebu clans. These clans have common traditions of origin centered on Akashiada, their eponymous ancestor. A tradition of origin of Akashiada recorded by Okolugbo claims that Akashiada and his followers arrived in the area in a wave of migration from Benin during the fifteenth century. They therefore founded the Akashiada group of villages. But given that the clans in question bear Igbo names, it is doubtful if they actually came from Benin as Okolugbo claims.

However, an oblique lead could be deciphered from a recent tradition we collected. According to it, the Akashiada and his followers migrated to their present location from Eastern Nigeria wave by wave and settled first at Umuoshi quarters of Eziokpor (Enunwokwu).It suggests that the earlier tradition that traces Akashiada to heaven was only intended to mystify his personality and attract more respectability from the neighbouring communities. From Eziokpor further migrations were made as a result of which many communities were founded within the Akashiada clans.

Obiaruku is believed to have been founded by an Umuebu migrant by name, Mokka. He is said to have left with other people of Umuebu and settled at the present site of Obiaruku in about 1880 (Miller). According to the tradition, the principal object of this move was to form a settlement on the bank of the navigable Ethiope River. Mokka was later joined by the whole of the Okoso quarters who settled beside Mokka's settlement. However, the tradition tracing the founding of Obiaruku to Mokka has been 
contested. The tradition recorded by Ohadike says the first immigrants to Obiaruku were inhabitants of Awkuzu quarters. According to it, the Awkuzu residents of Obiaruku claim that their ancestors had left Awkuzu, in Eastern Igboland, to settle in Aboh and later moved on to take up residence at Umuebu. At Umuebu, they felt dissatisfied with their share of the land and decided to move into an uninhabited area now known as Obiaruku because the land there was better and larger than the land of Umuebu. They were later joined by their relatives they had left behind at Aboh. These people founded the Umundede. This was followed by further migration from Umuebu to join the earlier settlers at Obiaruku. The people of Umuebu on the other hand, claim that their ancestors migrated from Ebu (a Western Igbo community in the Asaba area), while the ancestors of those of Ezionum came from Asaba, Utchi (25-26) and Afor.

The traditions of origins of the Akashiada group suggest that the people are the most recent settlers in the Ukwuani area. Contrary to Okolugbo's suggestion that Akashiada migration into the Ukwuani area took place in the fifteenth century, it probably occurred in the seventeenth century and the final movement took place in the closing decades of the nineteenth century (1880) as the case with Obiaruku. This is buttressed by the fact that almost all the sections of the Akashiada clans claim origin from existing Western Igbo communities such as Asaba, Ebu, Utchi and Afor in a tertiary migration.

\section{Akoku and Umutu Clans}

Akoku and Umutu clans have common origins. Tradition of origin of Akoku shows that the clan was founded as a result of four different waves of migrations into the area which comprised the four different quarters into which Akoku is divided. According to 
the tradition recorded by Miller, the Umuaja quarter was the first to come having moved from Ute in the Ika area (Western Igbo) of Delta State. They were followed by the Obeti Quarter that came from Igala on the banks of the Niger. The next arrivals were the Umutu quarter from Abbi (Western Igbo) and Ugulu quarter that came from Ogwashi-Ukwu (18), also a Western Igbo town. From the tradition it is clear that the communities as a whole is related to other clans outside their geographical location namely Abbi, Ika and Umutu clans (All in the Western Igbo area). The different quarter's trace their roots to other clans but no longer have any social or religious connections with them.

The tradition of Umutu clan strongly believe that they are descendants of Utu, whose ancestors migrated from somewhere east of the Niger to the Ankarai country (the present Aboh) on the bank of the river Niger. The tradition does not state the exact place east of the Niger though it is believed to be the same place as Echalla from where Amacha, the founder of Abbi migrated from, through the present Aboh area (Aswuai). This explains the reason for the movement of the migrant group to Abbi in secondary migration. They were said to have lived at Abbi for so many years before moving to their present location. This movement would probably had taken place at the later part of the sixteenth century or early seventeenth century given that Abbi was founded during the fifteenth century. But at the present Umutu no longer claim any relationship with Abbi.

On the arrival of the four groups they settled near a pond on the marshy areas of Akoku land. Uti identifies an Isoko migrant hunter from Ibrede amongst them. In one of his hunting expeditions, he is said to have discovered a long stretch of land which was level and more suitable for the groups. He therefore called all the family groups to settle on the land (2). When the 
family groups finally settled, four quarters were recognized. These were Obeti, Umutu, Umuaja and Ugulu. They became known collectively as Akoku. It later became the parent village of UmutuOgo, Umuaja and Obeti. These settlements in their present sites near the bank of river Ethiope were founded from Akoku in about 1860 (Uti 82) probably to ward off Benin encroachment through her settlement of Urhonigbe.

\section{Amai Clan}

According to the tradition recorded by Okolugbo, the founder of Amai clan was an elephant hunter called Amai from Igala who, in the course of his hunting expedition reached and decided to settle there. On his return to Igala he persuaded his family and kinsmen who followed him to settle in the new place. The tradition identifies the four sons of Amai, namely (in other of seniority) Ekwum, Nge, Aguma and Osele, who later founded the UmuEkwum, Amai-Nge, Ishikaguma and Umuosele quarters of Amai.

Another tradition links the ancestors of Amai with those of Abbi and Umukwata (collectively referred to as Umu-Nze) who left Echalla in Eastern Nigeria and sojourned first at Aboh before moving to their present settlements. However, a tradition mentions Igwete, an Igbo town east of the Niger as the ancestral home of Amai people, and this is why Amai is popularly referred to as Amai-Igwete (Edeme). The tradition recognizes that Amai and his group arrived Aboh where they met Amacha and his brother, Ukwuata, the founders of Abbi and Umukwata clans.

\section{Utagba-Unor and Related Clans}

Utagba-Unor, Utagba-Ogbe, Onicha-Ukwuani and Emu clans are united by ties of origin and migration. According to the tradition recorded by Izuegbu, Ikilibi quarter of Utagba-Uno was founded 
by a migrant band led by one Eziza (later Ezizanweani) from Akumazi in Ika land in the fifteenth century. They are said to have settled first on the eastern side of river Adofi (located at the extreme end of Etua, one of the Utagba quarters and empties into the River Niger through Iselegu and Ossissa) and later crossed it to settle in their present site in Utagba-Uno. In his party were Adoh, Isama, Ugbo, Nzei and Chioma. In the new site, Ezizanweani developed elephantiasis (which Izuegbu erroneously called hernia) of such a proportion that it became something of tourist attraction as many people in the neighbourhood trooped to catch a glimpse of it. The occasion of watching a person of so large scrotal elephantiasis was Ikiliibi (watching elephantiasis). With time the name Ikiliibi, stuck to Ezizanweani and his settlement (3-4).

A version of Umu-Onicha group popular among the Umuseti section claims the group led by Adamgbodongbo believed to have fled Benin with his group, including his four children, namely Ezeti, Ezeodu, Ezemu and Isulumani and sojourned first at Onicha-Olonaen route their present site in Utagba-Uno. The tradition says they were helped by several alligators that lined themselves forming a bridge on which they crossed the river Niger. As a result, the people believe they owe their survival to the alligator, which they call "Nnem-Onicha", that they see themselves as its children, that is, Umu-Onicha. The alligator has thus become their totem. The tradition goes on to say that later, Ezeodu and Ezemu migrated to other areas to found their respective communities of Onicha-Ukwuani and Emu clans. In the meantime, Adamgbodongbo had died, leaving Ezeti and Isulumani on the land, who later founded Umuseti and Isumpe quarters of UtagbaUno, respectively (Izuegbu).

However, another version of their tradition propagated by the Isumpe section traces their origin to their grand ancestor by 
name Epumegede who originally migrated from Egbema in Imo State to Onitsha, where he lived for some time. Later, he crossed the Niger with his group to their present site in Utagba-Uno. The Isumpe tradition appears to be more credible. For instance, if the group fled from Benin to Onicha-Olona, (a Western Igbo town), would they have had any business crossing the river Niger en route their present homeland? Besides, they also have the praise names: "EgbemaOkaNtu and Ndefuniogwujunli, meaning, respectively, Egbeme, the sharp shooters, and those, who, asked to choose between food and war, chose the latter".

The tradition also mentions that there were some OnichaOlona elements in Epumegede migrant band originally comprising his three sons, namely Isulumani, Ezeti and Ezeodu and other followers from Egbema. It goes to show that the founders of Umuseti and Isumpe quarters of Utagba-Uno migrated from Egbema in Eastern Igboland and sojourned for sometime at Onicha-Olona. The difference in the name of the founding ancestor was a recent event constructed when the two quarters were pitched against each other over the issue of seniority. But Ezeti, Ezeodu (the founder of Onicha-Ukwuani) and Isulumani were of the same parentage with Ezeti as the eldest. Their movement to the area would have occurred in the distant past, perhaps during the early fifteenth century (Egwuenu, 1998). There is also Awka element (Awamaka or Umu-Oka) among the Isumpe people. They are believed to be Awka blacksmiths who arrived in the area around the sixteenth century (Egwuenu14-17).

Umu-Nsukwa group comprising Umusadeli, Umusam, Umusadege and a section of Isumpe (OgbeNsukwaIsumpe) are said to have migrated from Nsukwa in Aniocha South Local Government Area of Delta State to their present sites (Miller 17; Edeme). The movement is believed to have been led by Ossai and 
Ezemagwu. On arrival in the territory they were said to have met older settlers, Ezizanweani and his people-the Ikilibi, and were virtually shoved out of the territory. The further settling, positioning, and partitioning of the territory was done by the migrants themselves (Izuegbu). The three brothers, namely Ezemagwu, Edeli and Adege founded Umusam, Umusadeli and Umusadege quarters of Utagba-Uno, respectively. Later, some families from these quarters migrated further to found Ogbe Nsukwa in Isumpe quarters. The inhabitants of the three UmuNsukwa quarters have always marked their migration from Nsukwa to their present homeland by the yearly all important feasts, Osa-Nsukwa.

Etua section of Utagba-Uno was founded by one Otor who migrated from Atuma in the present Oshimili North Local Government Area of Nigeria's Delta State. Otor and his group appeared to be unaware of the existence of the Ikilibi people until much later. They were later joined in the new settlement by one of the Ezizanweani children, Umenem, who founded a section of Etua.Utagba-Ogbe clan (now popularly called Kwale) was also founded as off-shoot of Utagba-Uno. Thus, the Utagba traditions indicate that the two clans are a mixture of Eastern and Western Igbo origins.

According to Utagba, OnichaUkwuani and Emu traditions, Eze-Odu and Eze-Emu carried on with the movement from Utagba-Uno and on their way Eweshi village of Onicha-Ukwuani was founded by Eze-Odu. Several other migrants founded other sections of the community such as Amoji-Ubulu founded by Ubulu migrants and the Ike-Onicha, Ugili-Amai and Ibabu-Onicha sections were founded from Nsukwa, a Western Igbo town. From Onicha-Ukwuani, Eze-Emu and Olor. (His brother's son) founded the present Emu-Uno, the head of Emu clan (Okoligwe). 


\section{Ogume and Ebedei Clans}

These two clans share common migration experience. In Ogbagu Ogume, there were Obodo-Etiti group said to have been founded by "some group of hunters, namely Ossai Ojugbeli, Ogwezi Omai and Mokobia and other group who together with Obodeti people were referred to as Umu-Ishiomi, in addition to Umu-Iyana led by Okpala Olodu and his younger brother, Ogwezi Olodu". There were Ase, Akarai and Umu-Iwele people who also settled in what became Ogbagu-Ogume. Ogbe-Ogume is said to have been settled first by two brothers, Ezede and Ifeloji who were later joined by Umu-Emo, Umu-Nkwoi and other migrants from Onya, a Western Igbo town in Ndokwa East Local Government Area of Nigeria's Delta State. Ogbole Ogumeis said to have been founded by Agbulu Akah who is believed to be among the group that emigrated from Benin.

There were other settlers in Ogbole Ogume such as the Ogwashi-Ukwu group led by Amanta, Umu-Ojieh family and other Onya migrants led by Ezulu. Ebedei tradition claims autochthonous origin (Milners), insisting that God had three sons who were the founders of Benin, Aboh and Ebedei and they were the first earth's inhabitants. Another tradition recorded by Ekele holds that Ebedei moved from a site near Ogume to their present location in a tertiary migration. From Ogbe-Uzu quarters, Adonishiaka was founded. A recent tradition we collected states that the founders of Ebedei were Igbo migrant iron-workers (Okpuzu) who migrated from Benin to the Ukwuani area.

They settled first at a site near Ogume but later migrated further to their new site owing to war with Ogume people over ownership of land (Enweliku).The first quarter they founded was Ogbe-Uzu (iron-workers quarters) in reverence to their profession. So, just how Benin are the Ukwuani people? It is interesting to 
note that all the clans have Igbo culture and traditions of origins. For example, Ifejioku, the cult of the earth goddess for which the Nri are famous was highly developed among the Ukwuani and Ndosimili; so too is the Ikenga and other religious paraphernalia for which the Igbo are distinguished. One cannot therefore generalise that the Ukwuani are Bini but it is possible that the border areas like the Ebedei have Bini element in their midst. This can also be true of some elements in Obiaruku who identify with Umusume movement. However, a recent tradition we collected indicates that this set of people were actually itinerant Igbo metal smiths who were expelled during the sixteenth century following the crisis that greeted the rise of Esigie to the Benin throne (Enweliku).This tradition is also held at Ogume and Emu clans where the people refer to themselves as okpuzu, an Igbo tern for iron-worker (Okoligwe).

\section{Conclusion}

The dominant narrative that the Ukwuani people are Benin immigrants is not supported by evidence. The people speak Igbo language (the most eloquent cultural badge), bear Igbo names and share similar religio - cultural traits with the Igbo of south-eastern Nigeria, which are obvious indications that they are Igbo settlers.

However, claims of origin from Benin by some Ukwuani communities may not be unconnected with their early contact with the Benin kingdom. The Igbo migrants appeared to have gone deep into Benin territory earlier to a place called Ado na Idu. Such movements might have continued for some time before being forced to recoil by Esigies's hostilities in the $16^{\text {th }}$ century. On their way they founded many settlements in the Western Igbo area including the Ukwuani land. It was that episode Okolugbo and others erroneously described as origins from Benin. 


\section{Paul O. Opone}

Department of History \& International Studies

Delta State University, Abraka

pauloshag@gmail.com;

opone@delsu.edu.ng

\section{Works Cited}

A.A.A Ekele. History and Culture of Ogume Clan. Lagos: Ebije Marketing Company, 2000.

Adiele, Afigbo, "Oral Tradition and Historical Explanation: A

Case Study from Central Southern Nigeria", in Nkparom C.

Ejituwu, ed. The Multi-Disciplinary Approach to African History: Essays in Honour of Ebiegberi Joe Alagoa. Port Harcourt: University of Port Harcourt Press, 1998, 61.79.

Anthony, Edeme. Personal Interview, Amai, 25 October, 2016.

Chief James, Ezulu. Personal Interview, Abbi, 27 August, 2012.

Chief John, Enunwokwu. Personal Interview, Eziokpor, 25 October, 2016.

Chief Julius, Enuenwosu. Personal Interview, Abbi, 27 August, 2012.

Daryll, Forde \& G.I Jones. The Ibo and Ibibio-speaking Peoples of South Eastern Nigeria. London: International African Institute, 1967.

Diokpa Anuka, Aswuai. Personal Interview, Umutu, 15 September, 2012.

Don, Ohadike..Anioma: A Social History of the Western Igbo. Athens: Ohio University Press 1994. 
Emmanual, Okolugbo. History of Ukwuani and Ndoshimili People of the Niger Delta. Benin City: Ethiope Publishing Corporation, 2004.

Ikechukwu, Izuegbu. Utagba-Uno: A Political History A.D $1600-$ 200. Ibadan: Spectrum Books Limited, 2003.

J.A. Atanda,. "The Historian and the Problem of Origins of

Peoples in Nigerian Society". Journal of the Historical Society of Nigeria, Vol. 10, No. 3, 1980, 63-77

Michael, Ozah. My Ukwuaniness. Lagos: Proudly Ukwuani Ventures, 2011.

NAI, File No. 2676184, G.B Williams, Intelligence Report on the Ibo Speaking Clans of the Kwale Division of the Province (1931).

NAI, File No. 29300, R.S. Mallison, An Intelligence Report on the Kwale-Ibo Clans, Kwale Division, Warri Province, (1939), $19-20$.

Obaro, Ikime. "The Rise and Fall of the Aboh Kingdom" in Obaro Ikime ed, History, the Historian and the Nation. (Ibadan: Heinemann Educational Books, 2006, 233 - 240.

Ogbolu, Enweliku. Personal Interview, Ebedei, 27 October, 2016. Samuel, Okoligwe. Personal Interview, Emu-Unor -29 May, 2016. 